Article

\title{
Biocarbon Derived from Opuntia ficus indica for $p$-Nitrophenol Retention
}

\author{
Hanedi Elhleli ${ }^{1,2}$, Faten Mannai ${ }^{1}$, Mongi ben Mosbah ${ }^{1,3}$, Ramzi Khiari 4,5,6 $\mathbb{D}$ \\ and Younes Moussaoui ${ }^{3,7, * \mathbb{D}}$ \\ 1 Materials, Environment and Energy Laboratory (UR14ES26), Faculty of Sciences of Gafsa, \\ University of Gafsa, Gafsa 2112, Tunisia; hanadi.hleli@gmail.com (H.E.); mannai_faten@yahoo.com (F.M.); \\ mbenmosbah@yahoo.fr (M.b.M.) \\ 2 Faculty of Sciences of Gabes, University of Gabes, Gabes 6029, Tunisia \\ 3 Faculty of Sciences of Gafsa, University of Gafsa, Gafsa 2112, Tunisia \\ 4 High Institute of Technological Studies (ISET), Ksar Hellal 5070, Tunisia; khiari_ramzi2000@yahoo.fr \\ 5 Faculty of Sciences, University of Monastir, UR13 ES 63-Research Unity of Applied Chemistry \& Environment, \\ Monastir 5000, Tunisia \\ 6 University of Grenoble Alpes, CNRS, Grenoble INP, LGP2, F-38000 Grenoble, France \\ 7 Organic Chemistry Laboratory (LR17ES08), Faculty of Sciences of Sfax, University of Sfax, Sfax 3029, Tunisia \\ * Correspondence: y.moussaoui2@gmx.fr
}

Received: 20 June 2020; Accepted: 24 September 2020; Published: 2 October 2020

check for updates

\begin{abstract}
Activated carbon obtained from Opuntia ficus indica by sodium hydroxide activation was employed for the adsorption of $p$-nitrophenol from water. The activated carbons obtained were characterized by Fourier transforms infrared spectroscopy, sorption of nitrogen, scanning electron microscopy, and Boehm titration. Effects of $\mathrm{pH}$, contact time, amount of adsorbent, and temperature on the adsorption of $p$-nitrophenol were studied. Adsorption isotherms were analyzed using Freundlich, Langmuir, Temkin, and Dubinin-Radushkevich models, and the thermodynamic parameters have been determined. The adsorption of $p$-nitrophenol was spontaneous, exothermic, and propitious at $15{ }^{\circ} \mathrm{C}$ and adopted the pseudo-second order model, and the most credible isotherm was Langmuir's one. The activated carbon used in this work has good $p$-nitrophenol adsorption characteristics, and the study of the desorption and reuse of this carbon shows that it retains a removal rate greater than $94 \%$ after five cycles of adsorption-desorption.
\end{abstract}

Keywords: porous carbon; activated carbon; adsorption; $p$-nitrophenol; Opuntia ficus indica

\section{Introduction}

Currently, one of the most serious environmental problems is pollution caused by human, agricultural, and industrial activity [1-4]. Thus, numerous studies make it possible to affirm that even at low levels, the pollution has unfriendly impacts on our health and our environment. Indeed, the effluents are often loaded with many pollutants that are not very biodegradable, which makes their treatments sometimes difficult to apply. Among the pollutants that pose a potential hazard to nature are phenolic compounds such as $p$-nitrophenol $[1,4,5]$. $p$-nitrophenol is a monocyclic organic compound, commonly utilized for peptides, dyes, explosives, and plastics synthesis, and is considered a forerunner for the synthesis of herbicides, fungicides, pesticides, and insecticides [6,7]. Therefore, $p$-nitrophenol is a typical example of sewage pollutants from many industrial processes, including agricultural, chemical, petrochemical, and pharmaceutical $[1,8]$. This compound is toxic to human health even at low concentrations and is indexed in the list of dangerous pollutants established by the United States Environmental Protection Agency [1]. In this respect, particular attention should 
be bestowed to $p$-nitrophenol and should be removed from wastewater before reuse or disposal. For that, a diversity of physicochemical and biological techniques has been implemented to clean up the wastewater loaded with $p$-nitrophenol. These techniques include the biological degradation [9], chemical precipitation [10], degradation [11-15], and adsorption on solid supports [1,5,16,17].

Among these techniques, adsorption has proved to be the easiest with good efficiency $[1,8,18]$ and the most used adsorbents to eliminate a wide variety of pollutants are activated carbons due to their highly developed porosity, good thermal stability, and variable surface area [19-24]. However, activated carbon is expensive, and its regeneration for possible reuse remains limited and makes it more expensive. To remedy this problem and reduce the cost of production of activated carbon, the use of agricultural and forestry waste as inexpensive, renewable resources and readily available as a precursor for making coal has heightened considerably. These resources include corncob wastes, banana peels, potato peels, date stones, pistachio wood, stems, bark, and shells, etc. [21-29]. Activated carbon is the preferred adsorbent for removing pollutants from wastewater [22,29-31]. Thus, the researchers focused on the production of activated carbon from biomass and renewable natural sources as an alternative to fully utilizing these resources [22,29-31]. Thus, Giuliano et al. [32,33] presented a sustainable approach to the use of biomass based on on-site use for the production of biofuels by lignocellulosic biorefinery with low $\mathrm{CO}_{2}$ emissions. This promotes the use of renewable biomass as a raw material for the production of various biobased products.

In this context, the Opuntia ficus indica was exploited in the present work as a forerunner to produce activated charcoal by carbonization and chemical activation using sodium hydroxide solution. Indeed, in Tunisia, Opuntia ficus indica is a widely planted biomass and appears in the form of a shrub with a height of up to $5 \mathrm{~m}$, and has an extraordinary water storage capacity [34,35]. This gives it the possibility of withstanding the climatic conditions of arid and semi-arid zones, and consequently a geographical distribution throughout the country, offering the possibility of being used industrially for the production of activated carbon. The activated carbon obtained was characterized by different physicochemical, morphological, and textural methods. The prepared adsorbent was used in batch mode for the retention of $p$-nitrophenol. To optimize the appropriate conditions for the retention of $p$-nitrophenol, the impact of the amount of adsorbent, the starting $\mathrm{pH}$, the contact time $(t)$, the starting $p$-nitrophenol concentration and the temperature $(T)$ on the $p$-nitrophenol suppression was studied. The kinetics and thermodynamics of the adsorption have been reported and the adsorption isotherms have been investigated using the Temkin, Freundlich, Dubinin-Radushkevich, and Langmuir models.

\section{Materials and Methods}

\subsection{Materials}

The trunk of Opuntia ficus indica (TOFI) was exploited as a forerunner to produce activated carbon. TOFI was reclaimed from the oasis of El-Guettar-Gafsa, southwest of Tunisia. The epidermal cells of the TOFI were removed, and then TOFI was rinsed repeatedly to withdraw sand and hydrophilic impurities. Finally, the TOFI was cut into chips $\left(3 \times 2 \times 1 \mathrm{~cm}^{3}\right)$. The resulting chips were desiccated at ambient for 7 days and thereafter dried at $105^{\circ} \mathrm{C}$ for $24 \mathrm{~h}$.

Sodium hydroxide $(\mathrm{NaOH}, 98 \%)$ and hydrochloric acid $(\mathrm{HCl}, 37 \%)$ were provided by Sigma-Aldrich (Tunis, Tunisia). Sodium carbonate $\left(\mathrm{Na}_{2} \mathrm{CO}_{3}, 99 \%\right)$, sodium bicarbonate $\left(\mathrm{NaHCO}_{3}, 99 \%\right)$, and $p$-nitrophenol ( $p$-NP, $\mathrm{C}_{6} \mathrm{H}_{5} \mathrm{NO}_{3}, 99.5 \%$ ) were provided by Fluka (Tunis, Tunisia).

\subsection{Adsorbent Preparation}

Activated carbon was produced in two stages, carbonization and activation. The raw material was pyrolyzed for $2 \mathrm{~h}$ in a tube furnace heated from room temperature to $450{ }^{\circ} \mathrm{C}$ with a gradient of $5{ }^{\circ} \mathrm{C} / \mathrm{min}$ under a nitrogen throughput of $100 \mathrm{~mL} / \mathrm{min}$. The cooling process was driven by the inertia of the oven. 
During chemical activation, the effect of the activation ratio was studied. For each test, $1 \mathrm{~g}$ of the biochar obtained after carbonization was impregnated for $2 \mathrm{~h}$ in $5 \mathrm{~mL}$ of a sodium hydroxide solution by varying the mass activation ratio $\left(\mathrm{RAM}=\mathrm{m}_{\mathrm{NaOH}} / \mathrm{m}_{\text {Biochar }}=0.5 / 1,1 / 1,2 / 1,3 / 1\right)$. The mixtures obtained were put in a basin of water at $50{ }^{\circ} \mathrm{C}$ for $24 \mathrm{~h}$. Afterwards, the samples were parched at $105^{\circ} \mathrm{C}$ until obtaining invariable mass. The carbons were chilled to room temperature and then pyrolyzed again within $100 \mathrm{~mL} / \mathrm{min}$ of nitrogen at $600^{\circ} \mathrm{C}\left(5^{\circ} \mathrm{C} / \mathrm{min}\right)$ for $2 \mathrm{~h}$. The obtained materials were chilled to ambient and washed successively with $0.1 \mathrm{~mol} / \mathrm{L}$ of $\mathrm{HCl}$ and distilled water in a soxhlet extractor until a neutral $\mathrm{pH}$ of the washing solutions was reached. The material obtained were desiccated at $105^{\circ} \mathrm{C}$ for $2 \mathrm{~h}$ and then ground and kept in a closed box.

The yield of the obtained carbon was calculated by applying Equation (1):

$$
R(\%)=\frac{\text { massofactivatedcarbon }(g)}{\text { initial mass }(g)}
$$

\subsection{Characterization}

Surface groups of prepared material were identified by Fourier Transform Infrared Spectroscopy (FTIR) analysis using a Shimadzu 8400 S spectrometer (France).

Textural parameters were obtained from $\mathrm{N}_{2}$ adsorption isotherms. The isotherms were obtained using a Micromeritics ASAP 2020, at $77 \mathrm{~K}$.

The $\mathrm{pH}$ of the zero-charge point ( $\mathrm{pH}_{\mathrm{ZCP}}$ ), acidic (carboxylic, lactonic, phenolic), and basic groups of obtained material were obtained as previously described [27]. The $\mathrm{pH}_{\mathrm{ZCP}}$ was measured using the $\mathrm{pH}$ drift method, which consists in plotting the graph of $\mathrm{pHf}=\mathrm{f}(\mathrm{pHi})$, wherepHi is the initial $\mathrm{pH}$ and $\mathrm{pHf}$ is the $\mathrm{pH}$ of the solution after addition of the activated carbon. Acidic groups were evaluated using the Boehm method [27]. A mass of carbon was added to basic solutions (sodium carbonate, sodium bicarbonate, and sodium hydroxide). The solutions were agitated and filtered. Then, a $\mathrm{HCl}$ solution was added to the obtained filtrates and neutralized by adding $\mathrm{NaOH}$ solution, and the equivalent points were determined. The number of functional groups was calculated taking into account that the $\mathrm{Na}_{2} \mathrm{CO}_{3}$ negates the carboxylic and lactonic groups, $\mathrm{NaHCO}_{3}$ negates the carboxylic groups, and $\mathrm{NaOH}$ negates the phenolic, lactonic, and carboxylic groups [27]. Basic groups were determined using $\mathrm{HCl}$ solution instead of basic solution [27]

The texture of carbon was examined by scanning electron microscopy using a Philips XL-30 instrument equipped with a charge-coupled device CCD camera.

\subsection{Adsorption of P-Nitrophenol}

The influence of adsorption parameters on the elimination of $p$-NP by active carbon was studied. These parameters include the initial $p$-NP concentration, the contact time, the $\mathrm{pH}$, the adsorbent dose, and the temperature.

Regardless of the parameter under study, the experiments were performed in a batch reactor by contacting a mass of the active carbon with $10 \mathrm{~mL}$ of $p$-NP solution $\left(C_{i}, \mathrm{mg} / \mathrm{L}\right)$ and brought to the desired temperature and $\mathrm{pH}$. The mixture is stirred, and after the given time, the samples are centrifuged and the residual concentration is measured using the method detailed by Obeid et al. [18]. This method involves mixing equal volumes of the $p$-NP solution to be analyzed and a solution of sodium carbonate $(0.5 \mathrm{~mol} / \mathrm{L})$ to ensure complete conversion to phenolate ions. The absorbance of the resulting mixture was measured by Beckman UV/Visible DU 800 spectrometer at $400 \mathrm{~nm}$.

The adsorption capacity $Q_{e}(\mathrm{mg} / \mathrm{g})$ was calculated conform to the Equation (2):

$$
Q_{e}=\frac{\left(C_{i}-C_{e}\right) \times V}{m}
$$

where, $C_{i}$ and $C_{e}(\mathrm{mg} / \mathrm{L})$ are the initial and equilibrium concentrations of $p-\mathrm{NP}, V(\mathrm{~L})$ is the volume of the $p$-NP solution, and $m(\mathrm{~g})$ the mass of the active carbon. 


\subsection{The Measurements of the Kinetics of P-Nitrophenol Adsorption}

The adsorption kinetics of $p$-NP on activated carbon was monitored at $\mathrm{pH}=2$ using a mass of $60 \mathrm{mg}$ of activated carbon while varying the initial $p$-NP concentration $(10,50,80,100$, and $150 \mathrm{mg} / \mathrm{L})$. The models of pseudo-first order (3) [36] and pseudo-second order (4) [37] were used to describe the obtained data.

$$
\begin{gathered}
\ln \left(Q_{e}-Q_{t}\right)=\ln Q_{e}-k_{1} t \\
\frac{t}{Q_{t}}=\frac{1}{k_{2} Q_{e}^{2}}+\frac{t}{Q_{t}}
\end{gathered}
$$

where, $Q_{e}$ and $Q_{t}(\mathrm{mg} / \mathrm{g})$ are, respectively, the adsorbed quantities at equilibrium and at time " $t$ ", while $k_{1}$ and $k_{2}$ represent the rate constants for pseudo-first and pseudo-second order adsorption, respectively.

\subsection{Modeling Isotherms}

The isotherms were obtained at 15,30 , and $40{ }^{\circ} \mathrm{C}$ under the selected operating conditions $(\mathrm{pH}=2$, $m=60 \mathrm{mg}, t=120 \mathrm{~min}$ ) while varying the $p-\mathrm{NP}$ concentration from 10 to $150 \mathrm{mg} / \mathrm{L}$. The experimental data were modeled using the theoretical models of Temkin, Freundlich, Dubinin-Radushkevich, and Langmuir (Table 1).

Table 1. Mathematical models and their linear forms.

\begin{tabular}{cccc}
\hline Isotherm & Non-Linear Form & Linear Form & Plot \\
\hline Langmuir [38] & $Q_{a d s}=\frac{C_{e} Q_{e} K_{L}}{1+\left(K_{L} C_{e}\right)}$ & $\frac{1}{Q_{a d s}}=\frac{1}{K_{L} Q_{e}} \frac{1}{C_{e}}+\frac{1}{Q_{e}}$ & $\frac{1}{Q_{a d s}} v s \frac{1}{C_{e}}$ \\
Freundlich [39] & $Q_{a d s}=K_{F} C_{e}^{\frac{1}{n}}$ & $\ln \left(Q_{a d s}\right)=\ln \left(K_{F}\right)+\frac{1}{n} \ln \left(C_{e}\right)$ & $\ln \left(Q_{a d s}\right) v s \ln \left(C_{e}\right)$ \\
Temkin [40] & $Q_{a d s}=\frac{R T}{B} \ln \left(A_{T} C_{e}\right)$ & $Q_{a d s}=\frac{R T}{B} \ln \left(A_{T}\right)+\frac{R T}{B} \ln \left(C_{e}\right)$ & $Q_{a d s} v s \ln \left(C_{e}\right)$ \\
Dubinin-Radushkevich [41] & $Q_{a d s}=q_{e} e^{-\beta \varepsilon^{2}}$ & $\ln \left(Q_{a d s}\right)=\ln \left(Q_{e}\right)-\beta \varepsilon^{2}$ & $\ln \left(Q_{a d s}\right) v s \varepsilon^{2}$ \\
\hline
\end{tabular}

$Q_{a d s}$ - the amount adsorbed $(\mathrm{mg} / \mathrm{g}), K_{L}$ - Langmuir constant $(\mathrm{L} / \mathrm{mg}), Q_{e}$ - the amount adsorbed at equilibrium $\left(\mathrm{mg}^{-1} \mathrm{~g}^{-1}\right)$, $C_{e}$ - the concentration of the solution at equilibrium $\left(\mathrm{mg} \cdot \mathrm{L}^{-1}\right), K_{F}$-Freundlich constant $\left(\mathrm{mg}^{(1-1 / \mathrm{n})} \cdot \mathrm{L}^{(1 / \mathrm{n})} \cdot \mathrm{g}^{-1}\right)$, $(1 / n)$-Freundlich coefficient, $B$-Temkin constant relating to heat of adsorption $\left(\mathrm{L} \cdot \mathrm{g}^{-1}\right), A_{T}$-Temkin constant relating to adsorption potential, $R$ - universal gas constant $(\mathrm{kJ} / \mathrm{kg} \mathrm{mol} \mathrm{K}), T$-temperature $(\mathrm{K}), \beta$-constant related to the mean free energy of adsorption $\left(\mathrm{mol}^{2} / \mathrm{kJ}^{2}\right), \varepsilon$-Polanyi potential.

\subsection{Errors}

To evaluate the concordance of the experimental data and the theoretical models, various error functions were used, namely the regression coefficient $\left(R^{2}\right)$, the root mean square residual error (EQRM), the chi-square error nonlinear analysis $\left(\chi^{2}\right)$, and normalized standard deviation $(\Delta Q)$.

$$
\begin{gathered}
\text { EQRM }=\sqrt{\frac{\sum_{i=1}^{n}\left(Q_{\text {exp }}-Q_{\text {mod }}\right)^{2}}{n}} \\
\chi^{2}=\sum \frac{\left(Q_{\text {exp }}-Q_{\text {mod }}\right)^{2}}{Q_{\text {mod }}} \\
\Delta Q=\sqrt{\frac{\sum\left[\left(Q_{\text {exp }}-Q_{\text {mod }}\right) / Q_{\text {exp }}\right]^{2}}{n-1}}
\end{gathered}
$$

$Q_{\exp }$ and $Q_{\text {mod }}$ are, respectively, the experimental adsorbed quantity and calculated from the model, $n$ is the number of measurement.

\subsection{Regeneration and Reuse}

To estimate the effectiveness of activated carbon from Opuntia ficus indica for repeated use after adsorption, the carbon was recovered and resuspended in $20 \mathrm{~mL}$ of a solution of sodium 
hydroxide $(0.1 \mathrm{~mol} / \mathrm{L})$ for $3 \mathrm{~h}$. Then followed centrifugation and washing with $30 \mathrm{~mL}$ of distilled water at $80{ }^{\circ} \mathrm{C}$. Finally, a centrifugation to recover the carbon, which will be dried at $105^{\circ} \mathrm{C}$ for $4 \mathrm{~h}$ to be used again.

\section{Results and Discussion}

\subsection{Caracterization of Activated Carbon}

The production of active carbon from Opuntia ficus indica was carried out in two stages: The first step is pyrolysis at $450{ }^{\circ} \mathrm{C}$. The second step involves activation and a second pyrolysis. Thus, we were interested in studying the effect of the impregnation ratio (Figure 1). The yield of active carbon passes through a maximum for a mass activation ratio equal to 2 . In this respect, an impregnation ratio of 2 and a pyrolysis time of $2 \mathrm{~h}$ at $600{ }^{\circ} \mathrm{C}$ will be taken as the optimum parameters for preparing activated carbon from Opuntia ficus indica.

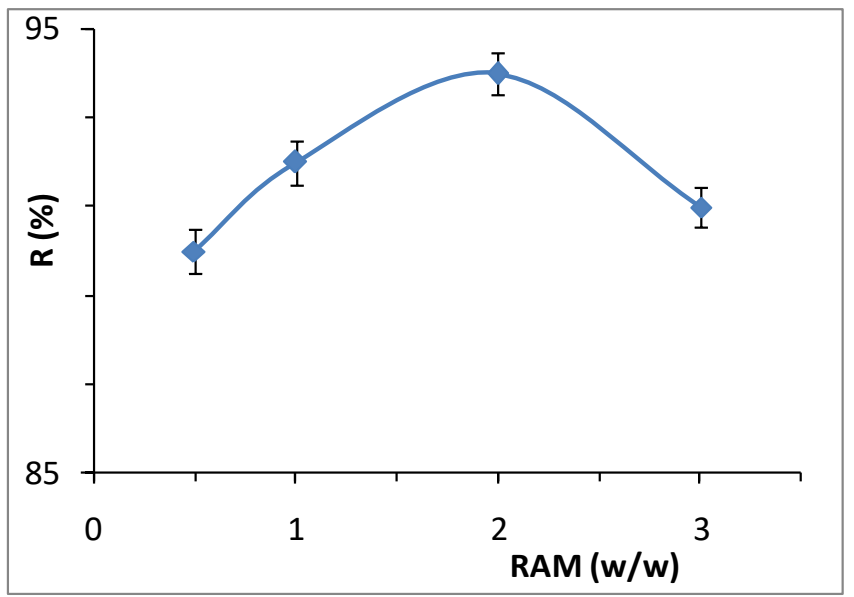

Figure 1. Effect of impregnation ratio on activated carbon yield.

The infrared spectrum of the activated carbon obtained under these conditions (Figure 2) has a broad band around $3439 \mathrm{~cm}^{-1}$ relating to the hydroxide $(\mathrm{OH})$ groups. A weak $1747 \mathrm{~cm}^{-1}$ band relating to the carbonyl elongation vibrations $(\mathrm{C}=\mathrm{O})$. An adsorption band at $1614 \mathrm{~cm}^{-1}$ attributed to the elongation vibrations of the $(\mathrm{OH})$ groups of the carboxyl groups.

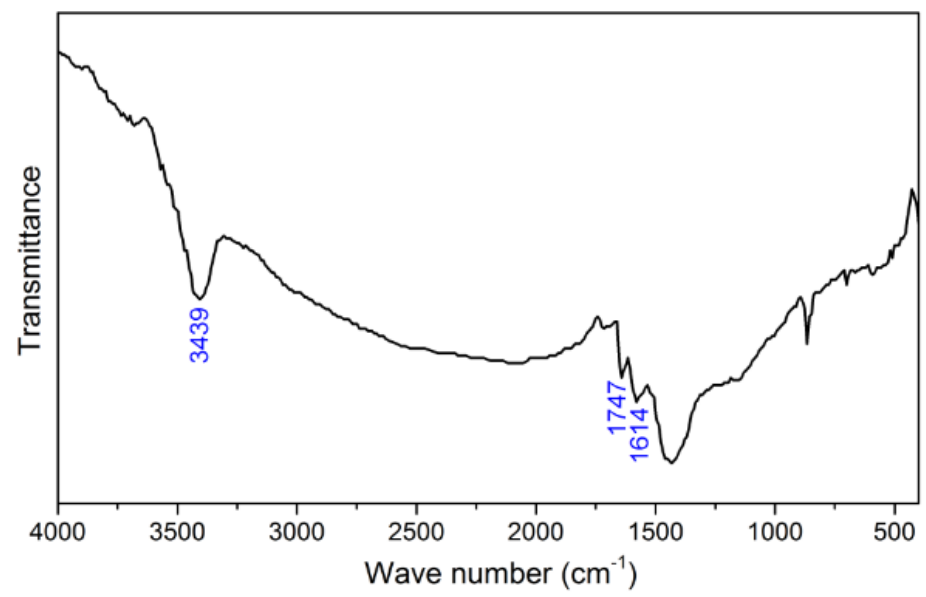

Figure 2. FTIR spectrum of activated carbon derived from Opuntia ficus indica. 
These findings confirm the Boehm titration results mentioned in Table 2. The obtained active charcoal has on its surface a number of basic groups greater than that of the acidic groups (lactonic, carboxylic, and phenolic) (Table 2). This confirms the basic character of coal where its $\mathrm{pH}_{\mathrm{ZCP}}$ is 9.1.

Table 2. Principal properties of active carbon.

\begin{tabular}{cc}
\hline Total pore volume $\left(\mathrm{cm}^{3} / \mathrm{g}\right)$ & 0.017 \\
Pore diameter $(\AA)$ & 55.35 \\
Specific surface $\mathrm{S}_{\mathrm{BET}}\left(\mathrm{m}^{2} / \mathrm{g}\right)$ & 332 \\
Carboxylic groups $(\mathrm{mmol} / \mathrm{g})$ & 0.243 \\
Lactonic groups $(\mathrm{mmol} / \mathrm{g})$ & 0.073 \\
Phenolic groups $(\mathrm{mmol} / \mathrm{g})$ & 0.294 \\
Total basic groups $(\mathrm{mmol} / \mathrm{g})$ & 0.756 \\
pH & 9.1 \\
\hline
\end{tabular}

Observation by scanning electron microscope shows that the activated carbon is structured and characterized by a very porous fibrous appearance (Figure 3). Activated carbon retained the lumen shape of the starting fibers with different size pores forming a mosaic of cells like a bee niche.
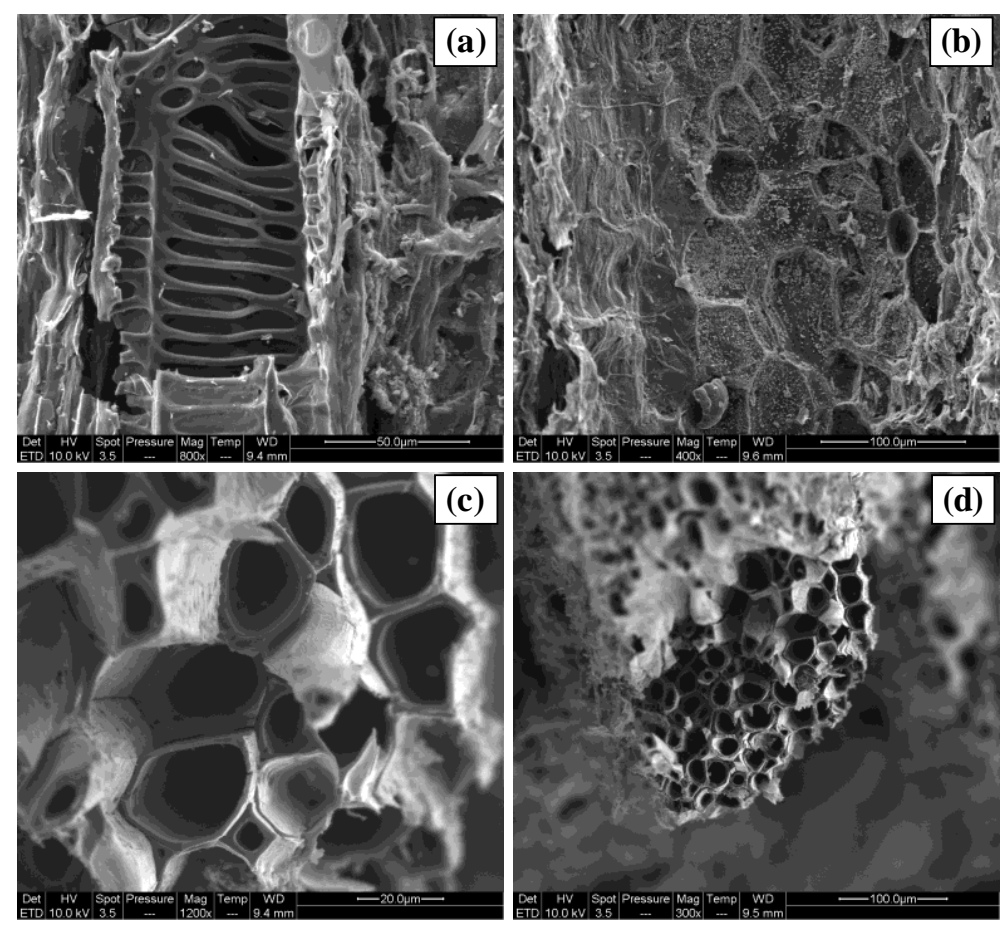

Figure 3. SEM microphotographs of active carbon: Surface, (a) and (b), section (c) and (d).

\subsection{Adsorption in Batch Mode}

\subsection{1. $\mathrm{pH}$ Effect}

The $\mathrm{pH}$ is an important factor influencing the adsorption, as it influences both the surface of the adsorbent and the functional groups of the adsorbate and hence the adsorption mechanism. The effect of $\mathrm{pH}$ on the retention rate of $p$-NP was studied by varying the $\mathrm{pH}$ from 2 to 12 (Figure 4). 


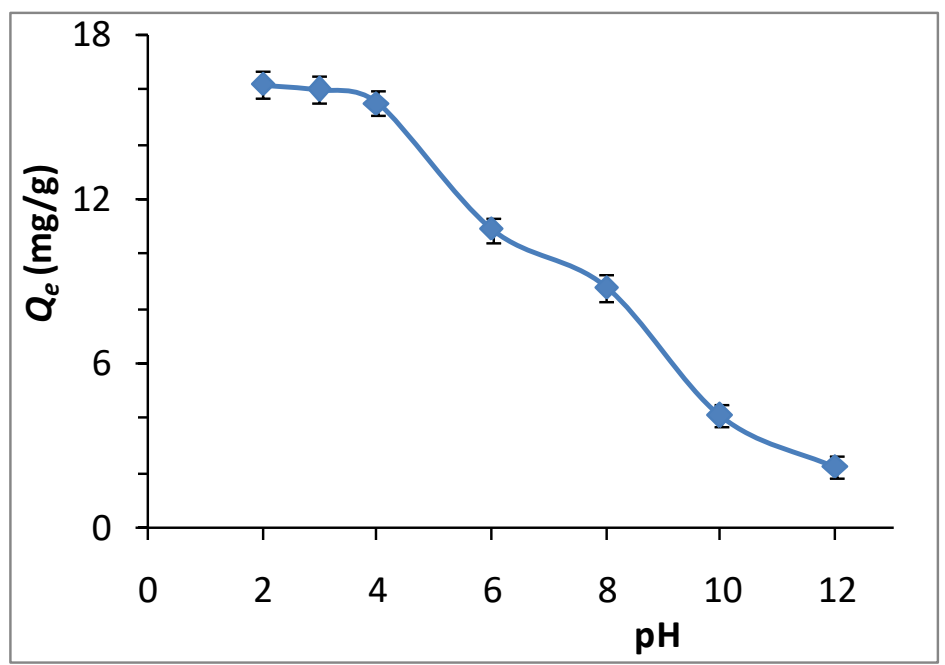

Figure 4. Effect of $\mathrm{pH}$ on adsorption of $p$-NP.

It seems that adsorption is favored in acidic medium. The adsorbed amount of $p$-NP varies slightly as the $\mathrm{pH}$ increases from 2 to 4 and then begins to decrease, which continues as the $\mathrm{pH}$ increases. This stipulates that the $p$-NP is preferably adsorbed on the surface of the active carbon in its molecular form, because at acid $\mathrm{pH}$ the $p$-NP, which has $\mathrm{pKa}$ of 7.15 [8], is in its molecular form. The decrease in adsorption capacity as the $\mathrm{pH}$ increases can be associated to the electrostatic repulsion existing between the surface of active carbon and the phenolate anions in solution [42]. Indeed, the $p$-NP begins to dissociate at $\mathrm{pH}=4$, while at the same time, the surface of active carbon is positively charged at $\mathrm{pH}$ lower than $\mathrm{pH}_{\mathrm{ZCP}}=9.1$ and takes a negative charge at $\mathrm{pH}>\mathrm{pH}_{\mathrm{ZCP}}$, which disadvantages the $p$-NP adsorption in basic medium. In this respect, the possible mechanism of adsorption can be envisaged by the electrostatic interactions between the surface groups of the active carbon and the functional groups of the $p$-NP. The aromatic cycle of $p$-NP forms a donor-acceptor complex with the carbonyl groups on the surface of active carbon, whose oxygen acts as an electron donor and the aromatic ring acts as an acceptor, hence the formation of a partially covalent bond. The nitro group is an electron withdrawing group that lowers the electron denseness in the $p$-NP cycle, which promotes the attraction of adsorbate molecules by the active carbon. This is in conformity with the literature. Ofomaja [42] investigated the use of mansonia wood sawdust for the retention of $p$-NP and has shown that adsorption is favored in acidic medium $(\mathrm{pH} \leq 4)$. Similarly, Cotoruelo et al. [43], Dhorabe et al. [8], and Petrova et al. [4] proved that an acidic medium is more suitable for the retention of $p$-NP on active carbons produced from lignin, Acacia glauca sawdust, and apricot stones.

\subsubsection{Effect of Mass of Adsorbent}

The variation of the adsorbed quantity and the removal rate of $p$-NP as a function of the adsorbent mass are shown in Figure 5. This study was carried out at $\mathrm{pH}=2$, while varying the amount of the adsorbent from 15 to $150 \mathrm{mg}$. The disappearance of the $p$-NP increases with the mass of the carbon until reaching a maximum elimination rate corresponding to a mass of $60 \mathrm{mg}$. The percentage removal of $p$-NP increased from $43.84 \%$ at a mass of carbon of $15 \mathrm{mg}$ to $99.26 \%$ at the mass of $60 \mathrm{mg}$. For an adsorbent mass greater than $60 \mathrm{mg}$, the removal rate of $p$-NP varies slightly. In fact, with the increase in the carbon mass, the number of adsorption sites increases, which causes agglomeration of the adsorbent particles. Consequently, a stabilization of the elimination rate will be observed with a decrease of the adsorbed quantity. So, a mass of $60 \mathrm{mg}$ of adsorbent will be chosen for the continuity of this work. 


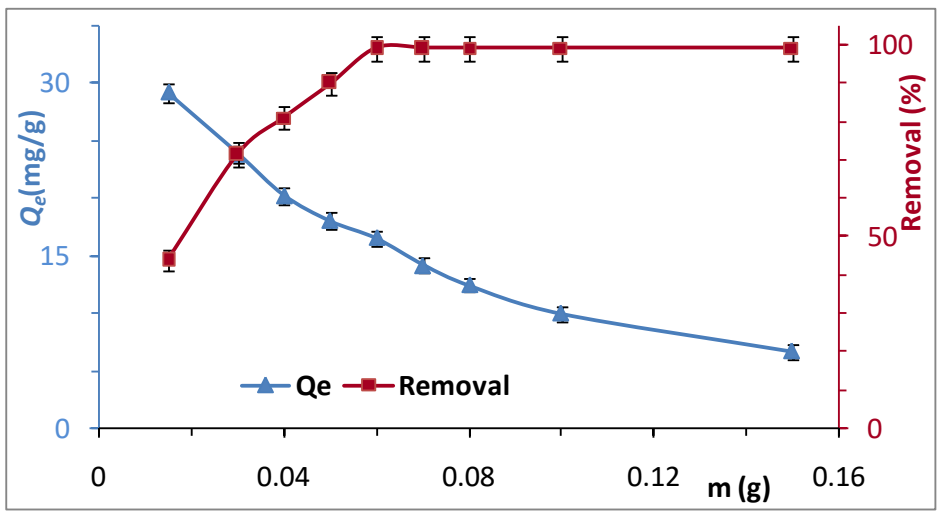

Figure 5. Mass effect on adsorption of $p$-NP.

\subsubsection{Effect of Contact Time}

In order to examine the impact of the contact time on the retention of $p$-NP, experiments were done at the chosen optimum $\mathrm{pH}(\mathrm{pH}=2)$, a mass of $60 \mathrm{mg}$ of adsorbent, and a volume of $10 \mathrm{~mL}$ of the $p$-NP solution $(100 \mathrm{mg} / \mathrm{L})$, varying the contact time from 20 to $1080 \mathrm{~min}$. The adsorbed quantity increases with increasing contact time (Figure 6).

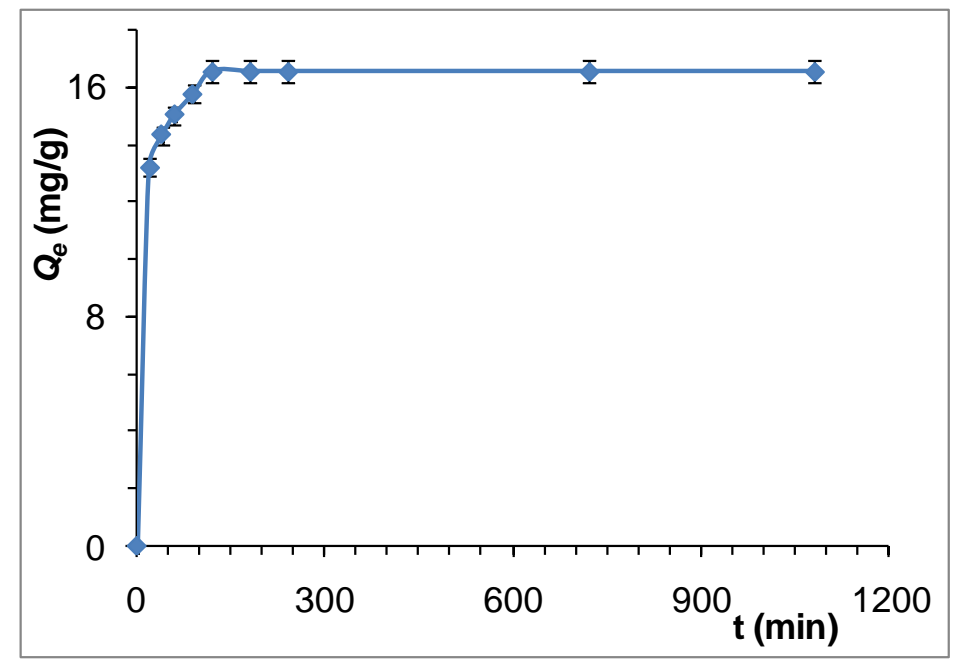

Figure 6. Effect of time on retention of $p$-NP.

The removal of $p$-nitrophenol is speedy up to $60 \mathrm{~min}$, and then slowly decreases to equilibrium for a duration of $120 \mathrm{~min}$. The initial step is distinguished by rapid adsorption linked to accessibility to active sites on the surface of the adsorbent, which results in a strong elimination of $p$-NP. After $120 \mathrm{~min}$, the $p$-NP removal percentage became constant, indicating that equilibrium has been reached. To ensure equilibrium, the optimum contact time has been guesstimated at $120 \mathrm{~min}$, which will be considered for the continuity of this study.

\subsubsection{Kinetics of Adsorption}

The kinetics study was carried out at $\mathrm{pH}=2$ using an adsorbent mass of $60 \mathrm{mg}$ while varying the initial concentration of $p$-NP $(10,50,80,100$ and $150 \mathrm{mg} / \mathrm{L})$. To dissect the adsorption process, pseudo-first order and pseudo-second order kinetic models were applied (Table 3). 
Table 3. Kinetic parameters of pseudo-first and pseudo-second order models for the adsorption of $p$-NP on activated carbon.

\begin{tabular}{ccccccc}
\hline \multicolumn{2}{c}{ Concentration $(\mathbf{m g} / \mathrm{L})$} & $\mathbf{1 0}$ & $\mathbf{5 0}$ & $\mathbf{8 0}$ & $\mathbf{1 0 0}$ & $\mathbf{1 5 0}$ \\
\hline & $Q_{\text {e-exp }}(\mathrm{mg} / \mathrm{g})$ & 1.647 & 8.147 & 12.453 & 14.467 & 14.901 \\
& $Q_{\text {e-cal }}(\mathrm{mg} / \mathrm{g})$ & 0.091 & 0.067 & 0.040 & 1.723 & 2.415 \\
\multirow{5}{*}{$\begin{array}{c}\text { Pseudo-first } \\
\text { order }\end{array}$} & $k_{1}\left(\mathrm{~min}^{-1}\right)$ & 0.005 & 0.004 & 0.003 & 0.006 & 0.005 \\
& $R^{2}$ & 0.726 & 0.894 & 0.440 & 0.761 & 0.881 \\
& $\chi^{2}$ & 190.43 & 8730.40 & 34211.28 & 839.93 & 609.88 \\
& $\Delta Q$ & 0.9821 & 1.1065 & 1.1177 & 0.8715 & 0.7947 \\
Pseudo-second & $E Q R M$ & 1.4795 & 8.0681 & 12.3758 & 12.6809 & 12.7932 \\
\hline order & $Q_{e-c a l}(\mathrm{mg} / \mathrm{g})$ & 1.666 & 8.176 & 12.453 & 15.174 & 16.420 \\
& $k_{2}(\mathrm{~g} / \mathrm{mg}$ & 0.157 & 0.278 & 0.337 & 0.011 & 0.007 \\
& $\mathrm{~min})$ & 1.000 & 1.00 & 1.000 & 0.999 & 0.999 \\
& $R^{2}$ & 0.08394 & 0.00298 & 0.002835 & 0.5185 & 1.21162 \\
& $\Delta Q$ & 0.0082 & 0.000046 & 0.000029 & 0.0052 & 0.0119 \\
\hline
\end{tabular}

Quantities of adsorbed $p$-NP $\left(Q_{e-c a l}\right)$ determined using the pseudo-second order model were very close to experimental ones $\left(Q_{e-e x p}\right)$, with much higher regression coefficients $\left(R^{2}\right)$ than those found by the kinetic model pseudo-first order. Similarly, the values of $\chi^{2}, E Q R M$, and $\Delta Q$ determined for the pseudo-second order model were lower than those obtained for the pseudo-first order model. This suggests that the $p$-NP adsorption on active carbon is dictated by the pseudo-second order model.

To better understand the number of steps and foresee the governing step of the adsorption process, we used the intraparticle model given by the following Equation (8):

$$
Q_{t}=k_{d i} t^{0.5}+C
$$

where, $k_{d i}\left(\mathrm{mg} \cdot \mathrm{g}^{-1}\right)$ is the intraparticle diffusion constant and $C$ is a constant.

The graphical representation of $Q_{t}$ versus $t^{0.5}$ for $100 \mathrm{mg} / \mathrm{L} p$-NP solution is shown in Figure 7. It shows two linearities, suggesting that the adsorption of $p$-NP can be dominated by more than one step. A rapid first step assigned to the diffusion of $p$-NP through the outer surface of the active carbon, comes after the intraparticle diffusion of $p$-NP molecules to the sites on the surface. The constant rates of intraparticle diffusion of the second part of the $Q_{t}=\mathrm{f}\left(\mathrm{t}^{0.5}\right)$ for different concentrations $(10-150 \mathrm{mg} / \mathrm{L})$ are presented in Table 4.

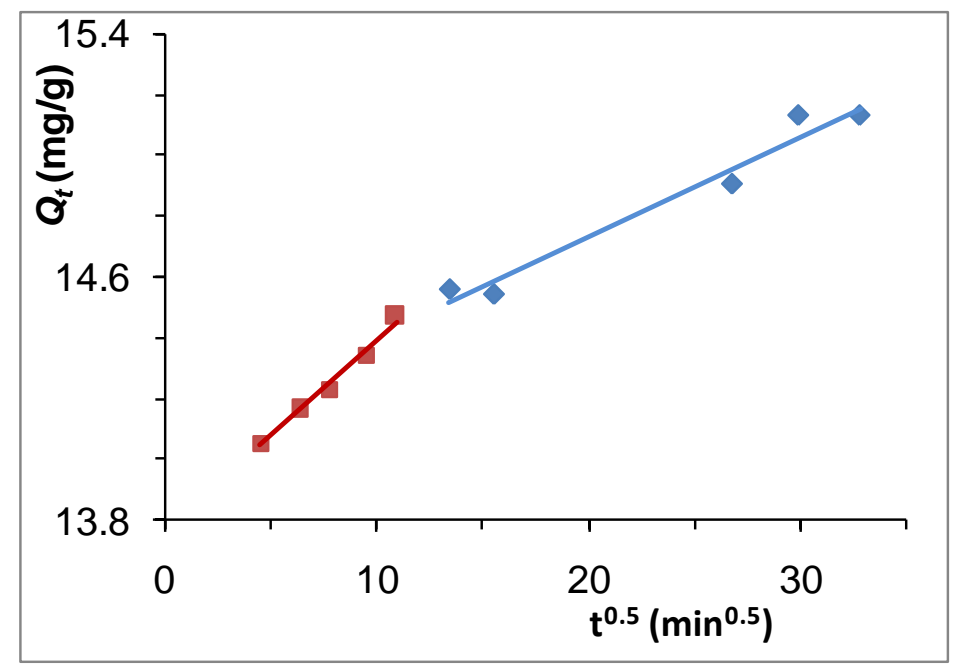

Figure 7. Kinetic model of intraparticle diffusion for the retention of $p$-NP $\left(C_{i}=100 \mathrm{mg} / \mathrm{L}\right)$. 
Table 4. Kinetic parameters of the intraparticle diffusion model for the retention of $p$-NP on activated carbon.

\begin{tabular}{cccccc}
\hline Concentration $(\mathbf{m g} / \mathrm{L})$ & $\mathbf{1 0}$ & $\mathbf{5 0}$ & $\mathbf{8 0}$ & $\mathbf{1 0 0}$ & $\mathbf{1 5 0}$ \\
\hline$Q_{e-c a l}(\mathrm{mg} / \mathrm{g})$ & 1.6522 & 8.154 & 12.453 & 14.438 & 2.415 \\
$k_{d i}\left(\mathrm{mg} / \mathrm{g}\right.$ min $\left.^{0.5}\right)$ & 0.0004 & 0.0009 & 0.0002 & 0.0326 & 0.027 \\
$C$ & 1.6479 & 8.1442 & 12.451 & 14.080 & 15.467 \\
$R^{2}$ & 0.918 & 0.976 & 0.495 & 0.968 & 0.913 \\
\hline
\end{tabular}

The second linear part of the intraparticle diffusion is an affine function, assuming that the latter was not the decisive step in the adsorption of $p$-NP. The correlation coefficient associated with this model $\left(R^{2}=0.82\right)$ is quite significant, which proves that intraparticle diffusion occurs during the adsorption of $p$-NP on active carbon.

The surface properties of activated carbon influence the adsorption process. The size of the $p$-NP molecule is approximately $7.5 \AA$ [16], whereas the activated carbon with an average pore size of $55 \AA$, and thus has a surface suitable for the retention of $p$-NP molecules. In addition, the adsorption of $p$-NP is favored through $\pi-\pi$ type interactions between the surface functions of activated carbon and the phenolic nucleus of $p$-NP. Indeed, the presence of the nitro group, electro-attracting effect on the $p$-NP enhances this interaction and generates hydrogen bonds between the surface functions $(\mathrm{COOH}, \mathrm{OH})$ with oxygen nitro groups in the $p$-NP.

\subsubsection{Adsorption Isotherms}

Adsorption isotherms provide information on the type and maximum capacity of adsorption. In this study, the Langmuir, Freundlich, Temkin, and Dubinin-Radushkevich isotherms were used for

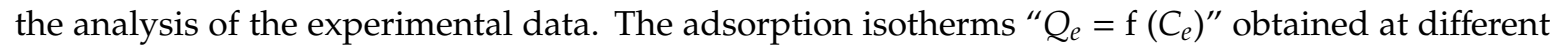
temperatures $\left(15^{\circ} \mathrm{C}, 30^{\circ} \mathrm{C}\right.$, and $\left.40{ }^{\circ} \mathrm{C}\right)$ by changing the initial concentration of $p$-NP from 10 to $150 \mathrm{mg} / \mathrm{L}$, are represented in Figure 8.

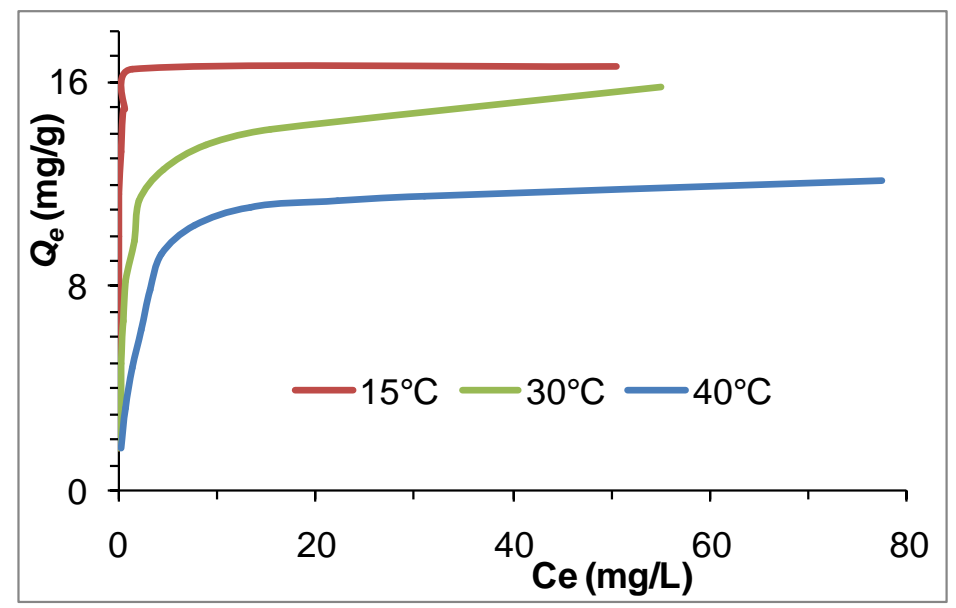

Figure 8. Adsorption isotherms of $p$-NP on active carbon.

The appearance of the curves proves that the present adsorption is of type $\mathrm{L}$ according to Giles and his collaborators [44], and that the adsorption of $p$-NP seems to be in monolayer. The results of the modeling of the experimental data according to the theoretical models of Langmuir, Freundlich, Dubinin-Radushkevich, and Temkin are illustrated in Table 5. 
Table 5. Values of the isothermal parameters at different temperatures.

\begin{tabular}{|c|c|c|c|c|}
\hline \multicolumn{2}{|c|}{ Temperature $\left({ }^{\circ} \mathrm{C}\right)$} & 15 & 30 & 40 \\
\hline \multirow{7}{*}{ Langmuir } & $Q_{\max }(\mathrm{mg} / \mathrm{g})$ & 16.835 & 13.623 & 12.738 \\
\hline & $K_{L}(\mathrm{~L} / \mathrm{mg})$ & 22 & 2.1524 & 0.4866 \\
\hline & $R_{L}$ & $0.0030-0.0045$ & $0.0030-0.0443$ & $0.0135-0.1704$ \\
\hline & $R^{2}$ & 0.9986 & 0.9981 & 0.9972 \\
\hline & $\chi^{2}$ & 0.2471 & 0.5748 & 0.1296 \\
\hline & $\Delta Q$ & 0.0023 & 0.0040 & 0.0019 \\
\hline & $E Q \widetilde{Q R M}$ & 0.5482 & 0.8159 & 0.3301 \\
\hline \multirow{6}{*}{ Freundlich } & $1 / n_{F}$ & 0.2312 & 0.3111 & 0.3442 \\
\hline & $K_{F}$ & 13.1615 & 6.7957 & 4.0551 \\
\hline & $R^{2}$ & 0.6591 & 0.8420 & 0.8258 \\
\hline & $\chi^{2}$ & 16.0993 & 5.3508 & 4.6874 \\
\hline & $\Delta Q$ & 0.3277 & 0.1052 & 0.0929 \\
\hline & $E Q R M$ & 5.4382 & 2.7908 & 2.2914 \\
\hline \multirow{6}{*}{ Temkin } & $B(\mathrm{~J} / \mathrm{mol})$ & 1.8330 & 2.2286 & 2.0725 \\
\hline & $A_{T}(\mathrm{~L} / \mathrm{g})$ & 1731.49 & 41.4929 & 10.2229 \\
\hline & $R 2$ & 0.8079 & 0.9712 & 0.9274 \\
\hline & $x^{2}$ & 5.2655 & 0.7642 & 1.2520 \\
\hline & $\Delta Q$ & 0.2602 & 0.0204 & 0.0338 \\
\hline & $E Q R M$ & 2.1942 & 0.7590 & 0.9398 \\
\hline \multirow{6}{*}{ Dubinin-Radushkevich } & $Q_{\max }(\mathrm{mg} / \mathrm{g})$ & 17.1209 & 11.8012 & 9.5020 \\
\hline & $\beta\left(\mathrm{mol}^{2} / \mathrm{kJ}^{2}\right)$ & 0.0126 & 0.0431 & 0.1449 \\
\hline & $R^{2}$ & 0.9924 & 0.9288 & 0.8720 \\
\hline & $\chi^{2}$ & 0.3163 & 3.2227 & 3.6093 \\
\hline & $\Delta Q$ & 0.0041 & 0.0351 & 0.0631 \\
\hline & $E Q \widetilde{Q R M}$ & 0.5497 & 1.7442 & 1.6527 \\
\hline
\end{tabular}

The regression coefficients $\left(R^{2}>0.99\right)$ obtained from the Langmuir model at different temperatures are the highest, indicating that this model is the appropriate one for drawing the adsorption of $p$-NP on activated carbon. This result is verified by the low values of $\chi^{2}, \Delta Q$, and EQRM. This suggests monolayer coverage of $p$-NP on the surface of activated carbon.

Values of the equilibrium constant of the Langmuir isotherm $\left(R_{L}\right)$, determined from Equation (9), range from 0 to 1 , indicating that retention of $p$-NP onto active carbon is propitious in the conditions adopted in this work. This is confirmed by the $1 / n_{F}$ values of the Freundlich model, which are less than 1.

$$
R_{L}=\frac{1}{1+K_{L} C_{0}}
$$

In addition, the increase in $R_{L}$ associated with the increment in temperature indicates that adsorption is more pronounced at low temperature $[17,45]$. This results in a decrease in the amount of adsorbed from 16.83 to $12.73 \mathrm{mg} / \mathrm{g}$ by raising the temperature from 15 to $40{ }^{\circ} \mathrm{C}$. In the same context, the values of the Freundlich constant $\left(K_{F}\right)$, which are directly related to the adsorption capacity, decrease with increasing temperature, proving that the retention is disadvantage at high temperature.

\subsubsection{Thermodynamic Study}

Thermodynamic parameters $\Delta G^{\circ}, \Delta H^{\circ}$, and $\Delta S^{\circ}$ were estimated by Equations (10) and (11) [46] (Table 6).

$$
\begin{aligned}
\Delta G^{\circ} & =-R T \ln K_{L} \\
\ln K_{L} & =\frac{\Delta S^{\circ}}{R}-\frac{\Delta H^{\circ}}{R T}
\end{aligned}
$$


where, $K_{L}(\mathrm{~L} / \mathrm{mol})$ is the Langmuir constant, $\mathrm{R}$ is the perfect gas constant $(8.314 \mathrm{~J} / \mathrm{mol} \mathrm{K})$, and T $(\mathrm{K})$ is the absolute temperature. $\Delta H^{\circ}$ and $\Delta S^{\circ}$ are obtained from the slope and the ordinate at the origin of the linear curve $\ln K_{L}=\mathrm{f}(1 / T)$.

Table 6. Thermodynamic parameters of the adsorption of $p$-NP.

\begin{tabular}{cccc}
\hline Temperature $(\mathrm{K})$ & $\Delta G^{\circ}(\mathrm{J} / \mathbf{m o l})$ & $\Delta H^{\circ}(\mathrm{J} / \mathbf{m o l})$ & $\Delta S^{\circ}(\mathrm{J} / \mathbf{m o l ~ K})$ \\
\hline 288 & -35756.70 & & \\
303 & -31762.92 & -114114.43 & -271.99 \\
313 & -28939.15 & & \\
\hline
\end{tabular}

The negative value of the free enthalpy $\left(\Delta H^{\circ}=-114114.43 \mathrm{~J} / \mathrm{mol}\right)$ demonstrates an exothermic adsorption. The values of $\Delta G^{\circ}$ are negative, which indicates that the adsorption of $p$-NP is spontaneous. Values of $\Delta G^{\circ}$ are less than $-20 \mathrm{~kJ} / \mathrm{mol}$, demonstrating that adsorption is governed by a physisorption partially affected by chemisorption. Moreover, $\Delta G^{\circ}$ increases with the temperature from $-35.75 \mathrm{~kJ} / \mathrm{mol}$ at $288 \mathrm{~K}$ to $-28.93 \mathrm{~kJ} / \mathrm{mol}$ at $313 \mathrm{~K}$, which implies that $p$-NP adsorption on active carbon is more favorable at lower temperature. Finally, the negative value of $\Delta S^{\circ}(-271.99 \mathrm{~J} / \mathrm{mol} \mathrm{K})$ corresponds to a decrease in the disorder at the activated carbon-solution interface.

\subsubsection{Regeneration and Reuse of Activated Carbon}

After adsorption of $p$-NP, the adsorbent is recovered and reused for adsorption of $p$-NP again for five adsorption-regeneration cycles. The results obtained are collated in Table 7.

Table 7. Five cycles of adsorption-desorption of $p$-NP on activated carbon.

\begin{tabular}{ccc}
\hline Cycle & Adsorption (\%) & Desorption (\%) \\
\hline 1 & 99.3 & 99.1 \\
2 & 99.0 & 99.0 \\
3 & 98.5 & 99.0 \\
4 & 96.2 & 98.3 \\
5 & 94.0 & 98.0 \\
\hline
\end{tabular}

The adsorption capacity of activated carbon decreased slightly $(<6 \%)$ from the first to the fifth cycle. The small reduction in $p$-NP uptake indicates that sites on the carbon surface have retained their morphological properties. The adsorption of $p$-NP on activated carbon, resulting from Opuntia ficus indica, seems to be reversible. Thus, the spent adsorbent can be regenerated and reused after treatment with $0.1 \mathrm{~mol} \mathrm{~L}{ }^{-1}$ sodium hydroxide solution followed by washing and drying at $105^{\circ} \mathrm{C}$. Indeed, $p$-NP reacts with sodium hydroxide to form sodium phenolates which desorb readily from the activated carbon.

\section{Conclusions}

The adsorption of $p$-NP on active carbon obtained from Opuntia ficus indica by activation with sodium hydroxide was the subject of this work. The specific surface area of the obtained carbon was $332 \mathrm{~m}^{2} / \mathrm{g}$ to be used successfully for the retention of $p$-NP. The adsorption of $p$-NP on activated carbon is maximal at initial $\mathrm{pH}=2$, with a removal percentage of $99.3 \%$. The optimum adsorptions parameters were found to be: Adsorbent dose $=6 \mathrm{~g} / \mathrm{L}, C_{i}=100 \mathrm{mg} / \mathrm{L}$, temperature $=15^{\circ} \mathrm{C}$, and time $=120 \mathrm{~min}$. The kinetics study indicates that the retention of $p$-NP on the obtained carbon obeys the kinetic model of pseudo-second order. The experimental isotherms are more suitable to the Langmuir model at all temperatures studied. The thermodynamic analysis confirmed that the adsorption of $p$-NP on active carbon derived from Opuntia ficus indica was spontaneous and exothermic. With increasing temperature, the increase in $\Delta G^{\circ}$ values implies that the adsorption of $p$-NP is favored at low temperature. The desorption and reuse tests of the carbon used in this work have shown that 
this carbon can be a reusable adsorbent for five adsorption-desorption cycles for the removal of $p$-NP. Thus, because of its adsorbent properties and the availability of the precursor of this carbon, it can be prepared and used economically for the treatment of waste water polluted by $p$-NP. Opuntia ficus indica could be considered an interesting and promising source for low-cost preparation of activated carbon as efficient adsorbent for $p$-NP removal, which represents a good option, especially for the countries without forests.

Author Contributions: Conceptualization: H.E.; validation: F.M. and M.b.M.; investigation: H.E. and Y.M.; data curation: H.E. and R.K.; writing—original draft preparation: H.E. and F.M.; writing—review and editing: Y.M. All authors have read and agreed to the published version of the manuscript.

Funding: This research received no external funding.

Acknowledgments: The authors would like to express their deep gratitude to Mohamed Naceur Belgacem, Professor and Director of the Grenoble INP-Pagora, for his valuable advice and assistance. The authors also gratefully express their sincere gratitude to the "PHC-UTIQUE CMCU" (18G1132), as well as to the Tunisian Ministry of Higher Education for the financial support. Ramzi KHIARI received the "Young Researcher Encouragement Prize 2020", from the Tunisian Academy of Sciences, Letters and Arts Beit al-Hikma, Tunisia.

Conflicts of Interest: The authors declare no conflict of interest.

\section{References}

1. Hamidouche, S.; Bouras, O.; Zermane, F.; Cheknane, B.; Houari, M.; Debord, J.; Harel, M.; Bollinger, J.C.; Baudu, M. Removal of aromatic hydrocarbons from water by activated carbon from apricot stones. Chem. Eng. J. 2015, 279, 964-972. [CrossRef]

2. Ahsan, M.A.; Islam, M.T.; Hernandez, C.; Castro, E.; Katla, S.K.; Kim, H.; Lin, Y.; Curry, M.L.; Torresdey, J.G.; Noveron, J.C. Biomass conversion of saw dust to a functionalized carbonaceous materials for the removal of Tetracycline, Sulfamethoxazole and Bisphenol A from water. J. Environ. Chem. Eng. 2018, 6, 4329-4338. [CrossRef]

3. Rabti, A.; Hannachi, A.; Maghraoui-Meherzi, H.; Raouafi, N. Ferrocene-Functionalized Carbon Nanotubes: An Adsorbent for Rhodamine B. Chem. Afr. 2019, 2, 113-122. [CrossRef]

4. Petrova, B.; Budinova, T.; Tsyntsarski, B.; Kochkodan, V.; Shkavro, Z.; Petrov, N. Removal of aromatic hydrocarbons from water by activated carbon from apricot stones. Chem. Eng. J. 2010, 165, 258-264. [CrossRef]

5. Kumar, A.; Jena, H.M. Removal of methylene blue and phenol onto prepared activated carbon from Fox nutshell by chemical activation in batch and fixed-bed column. J. Clean. Prod. 2016, 137, 1246-1259. [CrossRef]

6. Guo, P.; Tang, L.; Tang, J.; Zeng, G.; Huang, B.; Dong, H.; Zhang, Y.; Zhou, Y.; Deng, Y.; Ma, L.; et al. Catalytic reduction-adsorption for removal of p-nitrophenol and its conversion p-aminophenol from water by gold nanoparticles supported on oxidized mesoporous carbon. J. Colloid Interf. Sci. 2016, 469, 78-85. [CrossRef]

7. Kusçu, O.S.; Sponza, D.T. Performance of anaerobic baffled reactor (ABR) treating synthetic wastewater containing p-nitrophenol. Enzym. Microb. Tech. 2005, 36, 888-895. [CrossRef]

8. Dhorabe, P.T.; Lataye, D.H.; Ingole, R.S. Removal of 4-nitrophenol from aqueous solution by adsorption onto activated carbon prepared from Acacia glauca sawdust. Water Sci. Technol. 2016, 73, 955-966. [CrossRef]

9. Lin, J.; Reddy, M.; Moorthi, V.; Qoma, B.E. Bacterial removal of toxic phenols from an industrial effluent. Afr. J. Biotechnol. 2008, 7, 2232-2238.

10. Gupta, V.K.; Ali, I.; Saleh, T.A.; Nayak, A.; Agarwal, S. Chemical treatment technologies for waste-water recycling-An overview. RSC Adv. 2012, 2, 6380-6388. [CrossRef]

11. Chen, Y.; Sun, F.; Huang, Z.; Chen, H.; Zhuang, Z.; Pan, Z.; Long, J.; Gu, F. Photochemical fabrication of $\mathrm{SnO}_{2}$ dense layers on reduced graphene oxide sheets for application in photocatalytic degradation of $p$-Nitrophenol. Appl. Catal. B Environ. 2017, 215, 8-17. [CrossRef]

12. Rabaaoui, N.; Saad, M.K.; Moussaoui, Y.; Allagui, M.S.; Bedoui, A.; Elaloui, E. Anodic oxidation of o-nitrophenol on BDD electrode: Variable effects and mechanisms of degradation. J. Hazard. Mater. 2013, 250-251, 447-453. [CrossRef]

13. Shang, K.; Li, W.; Wang, X.; Lu, N.; Jiang, N.; Li, J.; Wu, Y. Degradation of $p$-nitrophenol by DBD plasma/Fe $\mathrm{Fe}^{2+} /$ persulfate oxidation process. Sep. Purif. Technol. 2019, 218, 106-112. [CrossRef] 
14. Xiong, Z.; Cao, J.; Lai, B.; Yang, P. Comparative study on degradation of p-nitrophenol in aqueous solution by $\mathrm{mFe} / \mathrm{Cu} / \mathrm{O}_{3}$ and $\mathrm{mFe} \mathrm{e}_{0} / \mathrm{O}_{3}$ processes. J. Ind. Eng. Chem. 2018, 59, 196-207. [CrossRef]

15. Zhang, C.; Li, T.; Zhang, J.; Yan, S.; Qin, C. Degradation of p-nitrophenol using a ferrous-tripolyphosphate complex in the presence of oxygen: The key role of superoxide radicals. Appl. Catal. B Environ. 2019, 259, 118030. [CrossRef]

16. Bastami, T.R.; Entezari, M.H. Activated carbon from carrot dross combined with magnetite nanoparticles for the efficient removal of p-nitrophenol from aqueous solution. Chem. Eng. J. 2012, 210, 510-519. [CrossRef]

17. Luo, Z.; Gao, M.; Yang, S.; Yang, Q. Adsorption of phenols on reduced-charge montmorillonites modified by bispyridinium dibromides: Mechanism, kinetics and thermodynamics studies. Colloid. Surface. A 2015, 482, 222-230. [CrossRef]

18. Obeid, L.; El Kolli, N.; Talbot, D.; Welschbillig, M.; Bée, A. Influence of a cationic surfactant on adsorption of p-nitrophenol by a magsorbent based on magnetic alginate beads. J. Colloid Interf. Sci. 2015, 457, 218-224. [CrossRef]

19. Rehman, R.; Manzoor, I.; Mitu, L. Isothermal study of congo red dye biosorptive removal from water by SolanumTuberosum and PisumSatioum peels in economical way. Bull. Chem. Soc. Ethiop. 2018, 32, 213-223. [CrossRef]

20. Okeola, O.F.; Odebunmi, E.O.; Ameen, O.M. Comparison of sorption capacity and surface area of activated carbon prepared from jatrophacurcas fruit pericarp and seed coat. Bull. Chem. Soc. Ethiop. 2012, 26, 171-180.

21. Ao, W.; Fu, J.; Mao, X.; Kang, Q.; Ran, C.; Liu, Y.; Zhang, H.; Gao, Z.; Li, J.; Liu, G.; et al. Microwave assisted preparation of activated carbon from biomass: A review. Renew. Sust. Energ. Rev. 2018, 92, 958-979. [CrossRef]

22. Bibaj, E.; Lysigaki, K.; Nolan, J.W.; Seyedsalehi, M.; Deliyanni, E.A.; Mitropoulos, A.C.; Kyzas, G.Z. Activated carbons from banana peels for the removal of nickel ions. Int. J. Environ. Sci. Technol. 2019, 16, 667-680. [CrossRef]

23. Kazmierczak, J.; Nowicki, P.; Pietrzak, R. Sorption properties of activated carbons obtained from corn cobs by chemical and physical activation. Adsorption 2013, 19, 273-281. [CrossRef]

24. Mohan, D.; Sarswat, A.; Ok, Y.S.; Pittman, C.U. Organic and inorganic contaminants removal from water with biochar, a renewable, low cost and sustainable adsorbent-A critical review. Bioresour. Technol. 2014, 160, 191-202. [CrossRef] [PubMed]

25. Darweesh, T.M.; Ahmed, M.J. Batch and fixed bed adsorption of levofloxacin on granular activated carbon from date (Phoenix dactylifera L.) stones by $\mathrm{KOH}$ chemical activation. Environ. Toxicol. Phar. 2017, 50, 159-166. [CrossRef] [PubMed]

26. El-Nahas, S.; Salman, H.M.; Seleeme, W.A. Aluminum Building Scrap Wire, Take-Out Food Container, Potato Peels and Bagasse as Valueless Waste Materials for Nitrate Removal from Water supplies. Chem. Afr. 2019, 2, 143-162. [CrossRef]

27. Khadhri, N.; Saad, M.K.; ben Mosbah, M.; Moussaoui, Y. Batch and continuous column adsorption of indigo carmine onto activated carbon derived from date palm petiole. J. Environ. Chem. Eng. 2019, 7, 102775. [CrossRef]

28. Kyzas, G.Z.; Deliyanni, E.A.; Matis, K.A. Activated carbons produced by pyrolysis of waste potato peels: Cobalt ions removal by adsorption. Colloid Surf. A 2016, 490, 74-83. [CrossRef]

29. Vu, M.T.; Chao, H.P.; Trinh, T.V.; Le, T.T.; Lin, C.C.; Tran, H.N. Removal of ammonium from groundwater using $\mathrm{NaOH}$-treated activated carbon derived from corncob wastes: Batch and column experiments. J. Clean. Prod. 2018, 180, 560-570. [CrossRef]

30. Talat, M.; Mohan, S.; Dixit, V.; Singh, D.K.; Hasan, S.H.; Srivastava, O.N. Effective removal of fluoride from water by coconut husk activated carbon in fixed bed column: Experimental and breakthrough curves analysis. Groundw. Sustain. Dev. 2018, 7, 48-55. [CrossRef]

31. Zhu, Y.; Kolar, P.; Shah, S.B.; Cheng, J.J.; Lim, P.K. Avocado seed-derived activated carbon for mitigation of aqueous ammonium. Ind. Crop. Prod. 2016, 92, 34-41. [CrossRef]

32. Giuliano, A.; De Bari, I.; Motola, V.; Pierro, N.; Giocoli, A.; Barletta, D. Techno-environmental Assessment of Two Biorefinery Systems to Valorize the Residual Lignocellulosic Biomass of the Basilicata Region. Appl. Math. Eng. Prob. 2019, 6, 317-323. [CrossRef]

33. Giuliano, A.; Catizzone, E.; Barisano, D.; Nanna, F.; Villone, A.; De Bari, I.; Cornacchia, G.; Braccio, G. Towards Methanol Economy: A Techno-environmental Assessment for a Bio-methanol OFMSW/Biomass/Carbon Capture-based Integrated Plant. Int. J. Heat Technol. 2019, 37, 665-674. [CrossRef] 
34. Mannai, F.; Ammar, M.; Yanez, J.G.; Elaloui, E.; Moussaoui, Y. Alkaline delignification of cactus fibres for pulp and papermaking applications. J. Polym. Environ. 2018, 26, 798-806. [CrossRef]

35. Mannai, F.; Ammar, M.; Yanez, J.G.; Elaloui, E.; Moussaoui, Y. Cellulose fiber from Tunisian Barbary Fig “Opuntiaficusindica” for papermaking. Cellulose 2016, 23, 2061-2072. [CrossRef]

36. Lagergren, S. Zurtheorie der sogenannten adsorption geloesterstoffe. K. Sven. Vetensk. Handl. 1898, 24, 1-39.

37. Ho, Y.S.; McKay, G. Pseudo-second-order model for sorption processes. Process Biochem. 1999, 34, 451-465. [CrossRef]

38. Langmuir, I. The adsorption of gases on plan surfaces of glass, mica and platinum. J. Am. Chem. Soc. 1918, 40,1361-1403. [CrossRef]

39. Freundlich, H.M.F. Uber die adsorption in losungen. Z. Phys. Chem. 1906, 57, 385-470. [CrossRef]

40. Temkin, M.J.; Pyzhev, V. Recent Modifications to Langmuir Isotherms. ActaPhysiochimca URSS 1940, 12, 217-225.

41. Dubinin, M.M.; Radushkevich, L.V. Equation of the Characteristic Curve of Activated Charcoal. Proc. USSR Phys. Chem. 1947, 55, 331-333.

42. Ofomaja, A.E. Kinetics and pseudo-isotherm studies of 4-nitrophenol adsorption onto mansonia wood sawdust. Ind. Crops Prod. 2011, 33, 418-428. [CrossRef]

43. Cotoruelo, L.M.; Marques, M.D.; Diaz, F.J.; Rodriguez-Mirasol, J.; Rodriguez, J.J.; Cordero, T. Adsorbent ability of lignin-based activated carbons for the removal of p-nitrophenol from aqueous solutions. Chem. Eng. J. 2012, 184, 176-183. [CrossRef]

44. Giles, C.H.; Smith, D.; Huitson, A. A general treatment and classification of the solute adsorption isotherm. I. Theoretical. J. Colloid Interf. Sci. 1974, 47, 755-765. [CrossRef]

45. Fan, S.; Wang, Y.; Wang, Z.; Tang, J.; Tang, J.; Li, X. Removal of methylene blue from aqueous solution by sewage sludge-derived biochar: Adsorption kinetics, equilibrium, thermodynamics and mechanism. J. Environ. Chem. Eng. 2017, 5, 601-611. [CrossRef]

46. Kula, I.; Ugurlu, M.; Karaoglu, H.; Celik, A. Adsorption of Cd (II) ions from aqueous solutions using activated carbon prepared from olive stone by $\mathrm{ZnCl}_{2}$ activation. Bioresour. Technol. 2008, 99, 492-501. [CrossRef]

(C) 2020 by the authors. Licensee MDPI, Basel, Switzerland. This article is an open access article distributed under the terms and conditions of the Creative Commons Attribution (CC BY) license (http://creativecommons.org/licenses/by/4.0/). 